\section{Response of Grafted Juglans nigra to Increasing Nutrient Availability: Growth, Nutrition, and Nutrient Retention in Root Plugs}

\author{
K. Francis Salifu and Douglass F. Jacobs ${ }^{1}$ \\ Hardwood Tree Improvement and Regeneration Center, Department of \\ Forestry and Natural Resources, Purdue University, West Lafayette, IN \\ 47907 \\ Guillermo Pardillo and Mary Schott \\ American Forestry Technologies Inc., 7852W 200S, West Point, IN 47992
}

Additional index words. black walnut, fertilization, nitrogen, nursery, rootstock, scion

\begin{abstract}
We examined growth and nitrogen (N), phosphorus (P), potassium (K), and microelement nutrition of grafted black walnut (Juglans nigra $\mathbf{L}$.) seedlings exposed to increasing nutrient supply and grown in the greenhouse for 18 week. Plants were potted and grafted within the first 4 week, then fertigated once each week for a 7 -week period with a varying nutrient solution of $20 \mathrm{~N}-4.4 \mathrm{P}-16.6 \mathrm{~K}$ that delivered $0,1160,2320$, and $4620 \mathrm{mg} \mathrm{N} /$ plant. Plants were harvested at week 18. There was a positive mean growth response to increased fertilization, although trends were statistically similar across treatments. Leaf nutrient concentration ranged from 22 to $31 \mathrm{~g} \cdot \mathrm{kg}^{-1} \mathrm{~N}, 5$ to $14 \mathrm{~g} \cdot \mathrm{kg}^{-1} \mathrm{P}$, and 19 to $25 \mathrm{~g} \cdot \mathrm{kg}^{-1} \mathrm{~K}$. The $2320 \mathrm{mg} \mathrm{N} /$ plant treatment increased leaf nutrient content $18 \%$ to $86 \%$ for $N, 33 \%$ to $303 \%$ for $P$, and $23 \%$ to $58 \%$ for K compared with the control. Nitrogen efficiency decreased with increased $\mathbf{N}$ supply. Increased nutrient retention in the growing medium at higher fertility suggests root plugs could serve as immediate critical nutrient sources for grafted black walnut seedlings after outplanting. Study results suggests nursery fertilization can be used to improve the nutritional quality of grafted black walnut as well as store nutrients in root plugs for later utilization to benefit early establishment success.
\end{abstract}

Black walnut (Juglans nigra L.) is considered among the most valuable hardwood tree species in North America because of its high-quality timber and multiple uses (Ponder, 2004; Williams, 1990). Black walnut typically occurs as a minor component of mixed deciduous forests in central and eastern parts of the United States and in the deciduous forest region of southern Ontario (Williams, 1990). Although judicious nursery fertilization can lead to the production of high-quality seedlings with improved field performance (Landis et al., 2005; Salifu and Timmer, 2003; Smith et al., 2005), nutritional information is relatively unavailable for black walnut seedlings. Lack of nursery fertilization data for black walnut may be related to

\footnotetext{
Received for publication 26 Apr. 2006. Accepted for publication 28 May 2006. This research was financially supported in part by a van Eck Postdoctoral Research Scholarship, USDA Forest Service State and Private Forestry, and Purdue University. Fertilizer application during plant cultivation was conducted by American Forestry Technologies, Inc. C. Howard, C. Mahara, and J. Ross assisted with processing of plant samples. We thank the three anonymous reviewers for their critical and constructive appraisal of an earlier version of this article.

${ }^{1}$ To whom reprint requests should be addressed; e-maildjacobs@purdue.edu
}

the assumption that the large seed may provide sufficient nutrition for seedlings during the nursery stage. Similarly, internal remobilization of nutrients from rootstock could provide adequate nutrition to fuel new growth of grafted plants. Although field studies suggest black walnut seedling growth may increase (Jacobs et al., 2005; Ponder, 1998) or decrease (Beineke, 1986; Ponder, 1996, 2004) with fertilization, we are not aware of any published information to explain how walnut might respond to nutrient inputs at the nursery stage, especially for grafted stock. A clear understanding of how grafted black walnut plants respond to nutrient inputs may provide useful information to improve nutritional stock quality for better field performance. Additionally, a balance sheet of $\mathrm{N}$ input, uptake, and use efficiency in nursery fertilization programs will be useful to help guide decisions regarding efficient use of fertilizer (Dumroese and Wenny, 1992). Such information is not available for walnut.

Furthermore, it has been suggested that root plugs of container plants may serve as nutrient sinks and store excess nutrients not exploited by plants (Idris et al., 2004). These plugs may act as critical nutrient sources to meet early nutrient demand of newly transplanted seedlings (Idris et al., 2004; Timmer and Teng, 2004). In the present study, we examined this hypothesis by quantifying macro- and microelement status of the growing substrate used for growing grafted walnut under four fertility levels to characterize nutrient retention capacity of the medium. This information allowed us to evaluate the potential of the root plugs to serve as sinks for nutrients at the nursery stage and provide critical nutrient sources to help meet early plant demand after field transplant.

Thus, we examined growth and nutrition of grafted walnut seedlings in relation to increased nutrient supply over a 7-week fertigation period when grown for 18 week in the greenhouse. Additionally, we computed a balance sheet of $\mathrm{N}$ input, uptake, and use efficiency across the $\mathrm{N}$ availability gradient to help understand $\mathrm{N}$ dynamics in this plantsoil system. We tested the hypotheses that: 1) grafted black walnut plants will respond positively to increased nutrient availability; 2) seedling root plugs act as sinks for excess nutrients not exploited by plants, which will be demonstrated by increased nutrient retention in the growing medium at higher fertility; and 3) a nitrogen balance sheet will show the appropriate levels for $\mathrm{N}$ input, uptake, and use efficiency by plants.

\section{Materials and Methods}

Growth conditions. Scion material from one single clone (expired patent Purdue \#1) was grafted onto 2-year-old rootstock seedlings in Mar. 2005. The rootstock were raised from nuts collected locally in Indiana and sown in nursery beds in Fall 2002, germinating in Apr. 2003, and grown in the nursery for two summers (2003 and 2004). In Fall 2004, the rootstock seedlings were lifted from the nursery beds and potted into $2.8-\mathrm{L}$ Treepots (Stuewe and Sons, Corvallis, Ore.) filled with Scotts Metro-Mix 560 growing medium (The Scotts Co., Marysville, Ohio). This medium contains $35 \%$ to $54 \%$ composted pine bark, $20 \%$ to $30 \%$ processed coconut coir pith, $10 \%$ to $20 \%$ sphagnum peatmoss, $5 \%$ to $15 \%$ processed bark ash, and $5 \%$ to $15 \%$ horticultural perlite. Additional information on media physical properties and chemistry are presented and discussed in Salifu et al. (2006). The dormant rootstocks were kept in the greenhouse until Apr. 2005, when the grafting process took place. Plants were top-grafted at the stage of leaf burst and expansion. The grafting phase was accomplished within 4 week (Table 1). Subsequently, grafted plants were exposed to four fertility treatments. One treatment was a nonfertilized control. The other three fertility treatments consisted of weekly fertigation with Peat-Lite Special 20N-4.4P-16.6K plus microelements (The Scotts Co.). Within each fertigation treatment, the amount of $\mathrm{N}$ in the nutrient solution increased over time, resulting in a total $\mathrm{N}$ application over the 7-week period of $0,1160,2320$, and $4620 \mathrm{mg} \mathrm{N} /$ plant (Table 1). Total $\mathrm{N}$ consisted of $\mathrm{NH}_{4}-\mathrm{N}$ $(7.97 \%)$ and $\mathrm{NO}_{3}-\mathrm{N}(12.03 \%)$. Each treatment replication contained 24 seedlings grown in 2.8-L pots. Thus, the experiment consisted of a total of 96 plants per treatment. The four 
Table 1. Amount of nitrogen fertilizer supplied to grafted black walnut seedlings in irrigation for 7 weeks when grown for 18 weeks in a greenhouse. The same volume of irrigation $(1.6 \mathrm{~L})$ was supplied to each seedling at each fertigation event.

\begin{tabular}{|c|c|c|c|c|c|c|c|c|c|}
\hline \multirow{2}{*}{$\begin{array}{l}\text { Fertilizer rate } \\
\text { (mg/plant) }\end{array}$} & \multicolumn{9}{|c|}{ Amount of fertilizer in irrigation (mg) } \\
\hline & $\begin{array}{c}\text { April } \\
\text { Weeks } 1 \text { to } 4\end{array}$ & \multicolumn{3}{|c|}{ May } & \multicolumn{4}{|c|}{ May/June } & $\frac{\text { Total }}{7 \text { Weeks }}$ \\
\hline 0 (control) & Grafting phase & 0 & 0 & 0 & 0 & 0 & 0 & 0 & 0 \\
\hline 2320 & Grafting phase & 240 & 240 & 240 & 320 & 320 & 480 & 480 & 2320 \\
\hline 4620 & Grafting phase & 480 & 480 & 480 & 640 & 640 & 950 & 950 & 4620 \\
\hline
\end{tabular}

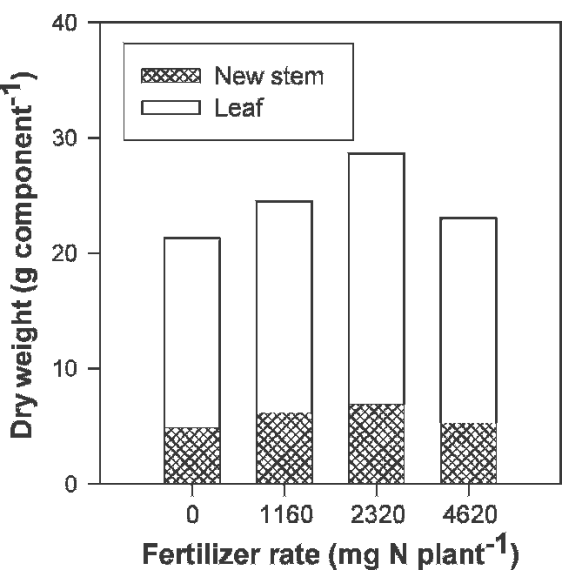

Fig. 1. Dry weight for scion components of grafted black walnut plants in relation to increased nitrogen supply at four fertility levels for 7 weeks when grown for 18 weeks in a greenhouse (see Table 1 for complete description of treatments).

fertility treatments were installed as a completely randomized design with four replications (384 plants total) and arranged on a greenhouse floor (mean temperature of $25^{\circ} \mathrm{C}$ ) under ambient light conditions at the American Forestry Technologies Inc. greenhouse facility in West Point, Ind. $\left(40^{\circ} 25^{\prime} \mathrm{N}\right.$, $\left.86^{\circ} 55^{\prime} \mathrm{W}\right)$. Fertilization commenced at week 5 , immediately after the grafting phase and continued for another 7 week (Table 1). Each plant was hose-irrigated with $\approx 1.6 \mathrm{~L}$ of the nutrient solution with $\mathrm{pH}$ corrected to 6.5 through injection with sulfuric acid at each fertigation event. Nitrogen supplied to plants (mg) was computed as the average ppm $\mathrm{N}$ of solution $\times$ total liters of irrigation applied as detailed in Dumroese and Wenny (1992). This information was used to construct a balance sheet of $\mathrm{N}$ input, uptake, and use efficiency.

Plant sampling, chemical and statistical analyses. Two pots were randomly sampled from each replicate (a total of eight plants) per treatment 18 week after planting. After harvest, roots were washed free of media, and seedlings were partitioned into leaves (part of scion), new stems (part of scion), old stem (part of rootstock), and roots (from rootstock). All samples were composited by treatment replication for nutritional analysis but measured individually and averaged for growth analysis. Plant material was oven dried for $48 \mathrm{~h}$ at $70{ }^{\circ} \mathrm{C}$ and ground. A complete nutritional analysis was conducted on these components at A \& L Great Lakes Laboratories (Fort Wayne, Ind.). Total $\mathrm{N}$ was
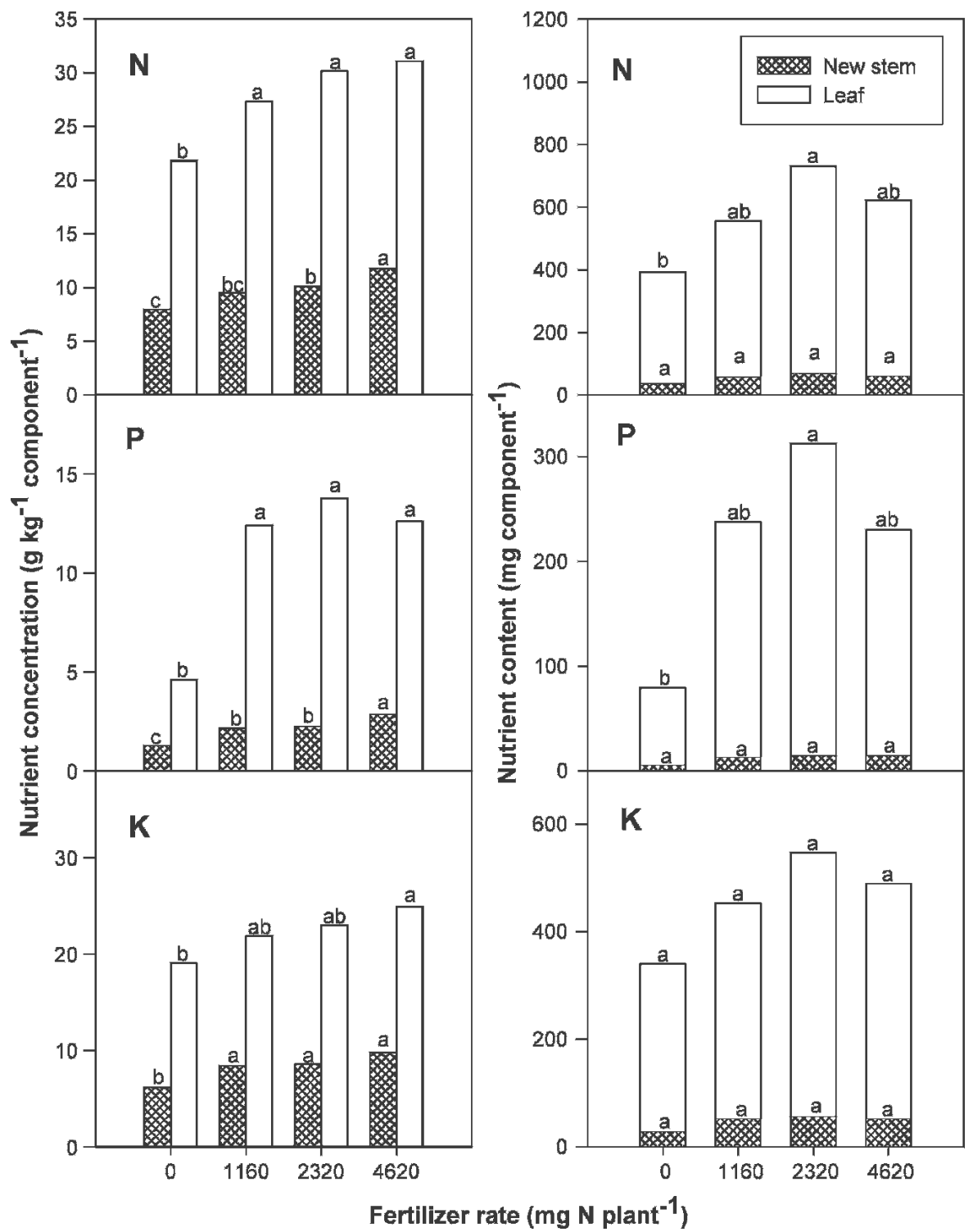

Fig. 2. Nutrient concentration (left) and nutrient content (right) for scion components of grafted black walnut plants in relation to increased nitrogen supply at four fertility levels for 7 weeks when grown for 18 weeks in a greenhouse (see Table 1 for a complete description of treatments). Similar bars marked with different letters differ statistically according to Tukey's honestly significant difference test $\alpha=0.05$.

determined by combustion "Dumas" procedure (Association of Official Analytical Chemist [AOAC] 968.06) using a LECO nitrogen analyzer (LECO Corp., St. Joseph, Mich.). Additionally, plant samples were digested in nitric + perchloric acids (AOAC 935.13) and the other elements determined using inductively coupled argon plasma (ICAP) analysis (AOAC 985.01). EC (EC), $\mathrm{NO}_{3}-\mathrm{N}, \mathrm{NH}_{4}-\mathrm{N}, \mathrm{P}$, and $\mathrm{K}$ of growing media sampled at harvest were determined from saturated aqueous extracts following procedures described in Brown (1997). Growth and nutritional data were subjected to one-way analysis of variance and significant $(P<0.05)$ means were ranked according to Tukey's honestly significant difference test at $\alpha=0.05$ using SAS software (SAS Institute, 2001). 
Table 2. Plant (root, old stem, new stem and leaf) $\mathrm{N}$ content, and microelement concentration in root plugs and in leaves of grafted black walnut plants exposed to increased fertility levels for 7 weeks when grown for 18 weeks in a greenhouse in 2005 .

\begin{tabular}{|c|c|c|c|c|c|c|c|c|c|}
\hline \multirow{2}{*}{ Fertilizer rate $\left(\mathrm{mg} \mathrm{N}\right.$ plant $\left.^{-1}\right)$} & \multirow{2}{*}{$\frac{\mathrm{N} \text { content }(\mathrm{mg})}{\text { Plant }}$} & \multicolumn{8}{|c|}{ Microelement concn $\left(\mathrm{mg} \cdot \mathrm{kg}^{-1}\right)$} \\
\hline & & \multicolumn{4}{|c|}{ Growing media } & \multicolumn{4}{|c|}{ Leaf } \\
\hline 0 (control) & $1460 \mathrm{~b}$ & $0.10 \mathrm{c}$ & $0.35 \mathrm{~b}$ & 0.10 & $0.10 \mathrm{~b}$ & 52.25 & $144.75 \mathrm{~b}$ & 123.75 & 51.00 \\
\hline 2320 & $2710 \mathrm{a}$ & $0.25 \mathrm{~b}$ & $0.38 \mathrm{~b}$ & 0.10 & $0.10 \mathrm{~b}$ & 66.25 & $166.75 \mathrm{ab}$ & 169.25 & 56.00 \\
\hline 4620 & $3050 \mathrm{a}$ & $0.48 \mathrm{a}$ & $1.10 \mathrm{a}$ & 0.38 & $0.20 \mathrm{a}$ & 69.50 & $190.50 \mathrm{a}$ & 220.50 & 41.00 \\
\hline ANOVA $P<F$ & 0.0084 & 0.0001 & 0.0014 & 0.1506 & 0.0097 & 0.0606 & 0.0077 & 0.2334 & 0.6233 \\
\hline
\end{tabular}

Column means followed by different letters differ statistically according to Tukey's honestly significant difference test $\alpha=0.05$.

\section{Results and Discussion}

Growth and nutrition. Growth of the new scion is partitioned into leaf and new stem as shown in Figs. 1 and 2. Seedlings fertilized at $2320 \mathrm{mg} \mathrm{N} /$ plant accumulated greater mean dry weight in leaves and new stems than the others, although the observed differences were nonsignificant $(P>0.05)$ (Fig. 1). This growth response is likely associated with induced luxury consumption in walnut seedlings, which is demonstrated by significant leaf $\mathrm{N}$ uptake (Fig. 2, right), but no differences $(P>0.05)$ in dry weight (Fig. 1). Such trends have been previously noted with fertilization of black spruce (Picea mariana Mill. BSP) seedlings (Salifu and Timmer, 2003). Decreased component dry weight at the highest fertility level suggests potential over fertilization. Total root dry weight was similar across all fertility treatments with means (SE) varying from 95 (11) g for the control, 89 (4) $\mathrm{g}$ for the $1160 \mathrm{mg} \mathrm{N} /$ plant treatment, 96 (20) g for the $2320 \mathrm{mg} \mathrm{N} /$ plant treatment, and 84 (7) $\mathrm{g}$ for the $4620 \mathrm{mg}$ $\mathrm{N}$ plant ${ }^{-1}$ treatment.

Leaves acted as sinks for nutrients as demonstrated by greater allocation to these tissues (Fig. 2). New stem and leaf N, P, and $\mathrm{K}$ concentrations increased with increasing $\mathrm{N}$ supply (Fig. 2, left). Nutrient levels in leaves of black walnut seedlings may range from 25 to $30 \mathrm{~g} \cdot \mathrm{kg}^{-1}$ for $\mathrm{N}, 2$ to $3 \mathrm{~g} \cdot \mathrm{kg}^{-1}$ for $\mathrm{P}$, and 13 to $15 \mathrm{~g} \cdot \mathrm{kg}^{-1}$ for K (Frak et al., 2005; Ponder, 2004). Additionally, over $26 \mathrm{~g} \cdot \mathrm{kg}^{-1}$ $\mathrm{N}, 2.5 \mathrm{~g} \cdot \mathrm{kg}^{-1} \mathrm{P}$, and $13 \mathrm{~g} \cdot \mathrm{kg}^{-1} \mathrm{~K}$ in leaves may be considered adequate for black walnut seedling growth (Ponder, 2004). Leaf nutrient concentrations ranged from 22 to $31 \mathrm{~g} \cdot \mathrm{kg}^{-1} \mathrm{~N}$, 5 to $14 \mathrm{~g} \cdot \mathrm{kg}^{-1} \mathrm{P}$, and 19 to $25 \mathrm{~g} \cdot \mathrm{kg}^{-1} \mathrm{~K}$ in this study (Fig. 2, left). This observation suggests nutrient levels were adequate in fertilized seedlings based on the recommendations by Ponder (2004). The similarity in $\mathrm{N}$ status noted in leaves of 2-year-old hybrid walnut (Juglans nigra $\times$ regia) trees (25-29 g $\left.\cdot \mathrm{kg}^{-1}\right)$ (Frak et al., 2005) with results of our study (Table 2) and those documented by (Ponder, 2004) support this contention. Nutrient levels in controls were below those recommended as adequate for growth of walnut seedlings (Fig. 2). This implies that native fertility of the media was inadequate for plant growth even in the short term, suggesting the need for nutrient supplementation when using such medium for raising plants.
Fertility treatments significantly affected plant (leaf, new stem, old stem and root combined) total N (Table 2). Similarly, leaf $\mathrm{N}$ and $\mathrm{P}$ contents increased with fertility, contrasting markedly with the observed similar uptake in new stems (Fig. 2, right). The $2320 \mathrm{mg} \mathrm{N} /$ plant fertility treatment was

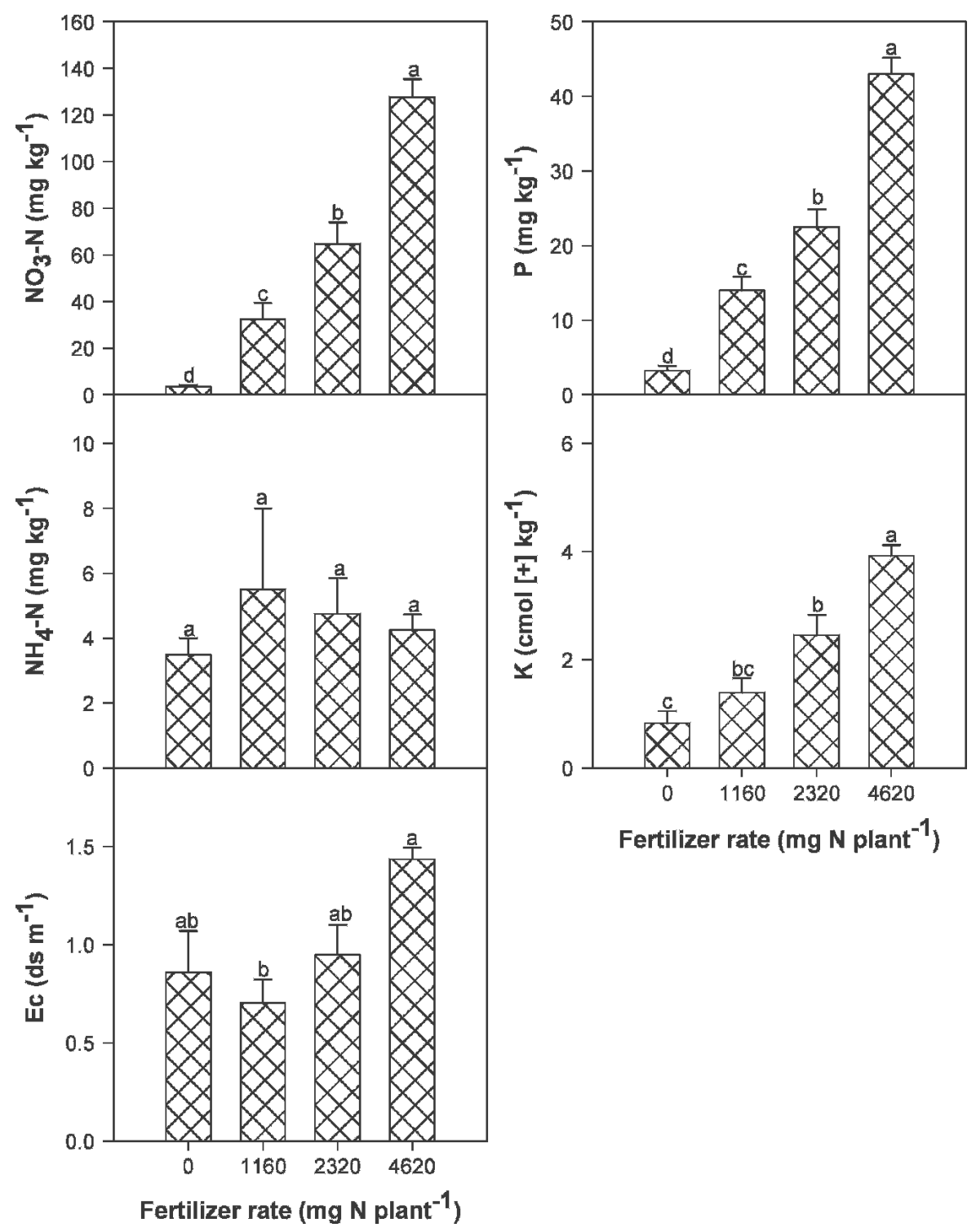

Fig. 3. Chemical characteristics of root plugs sampled from grafted black walnut seedlings exposed to increased nitrogen supply at four fertility levels for 7 weeks when grown for 18 weeks in a greenhouse (see Table 1 for a complete description of treatments). Similar bars marked with different letters differ statistically according to Tukey's honestly significant difference test $\alpha=0.05$. 
Table 3. Balance sheet of total irrigation, $N$ input from irrigation, $N$ uptake from fertilizer and use efficiency in grafted black walnut seedlings exposed to increased fertility levels for 7 weeks when grown for 18 weeks in a greenhouse in 2005 .

\begin{tabular}{|c|c|c|c|c|c|c|}
\hline \multirow[b]{2}{*}{ Fertilizer rate (mg N/plant) } & \multirow[b]{2}{*}{ Irrigation (1) } & \multirow[b]{2}{*}{ N Supplied (mg plant $\left.{ }^{-1}\right)$} & \multicolumn{2}{|c|}{ Total $\mathrm{N}$ content (mg) } & \multirow[b]{2}{*}{ Fertilizer N efficiency (\%) } & \multirow[b]{2}{*}{ Unaccounted $\mathrm{N}(\mathrm{g})$} \\
\hline & & & Whole plant & Fertilizer & & \\
\hline 1160 & 11.12 & 1160 & 2630 & 1170 & 102 & -0.01 \\
\hline
\end{tabular}

Note: $\mathrm{N}$ uptake from fertilizer obtained by deducting $\mathrm{N}$ content of the controls $(0)$ from the other treatments.

the growing medium (Fig. 3). Thus, the 2320 $\mathrm{mg} \mathrm{N} /$ plant treatment may represent the desired dose rate under the prevailing cultural conditions in this current study. However, we recommend further studies to examine a greater range of fertilizer inputs as well as to refine analysis of fertilizer responses between 1160 and $2320 \mathrm{mg} \mathrm{N} /$ plant and between 2320 and $4620 \mathrm{mg} \mathrm{N} /$ plant, which could improve diagnostic precision.

Generally, foliar microelement concentrations increased at higher nutrient inputs and differed for iron (Fe) (Table 2). Similarly, microelement concentrations of media increased with fertility and differed for boron (B), zinc ( $\mathrm{Zn})$, and Fe. Published foliar microelement concentrations considered adequate for growth of hardwood species may range from 80 to $90 \mathrm{mg} \cdot \mathrm{kg}^{-1}$ for $\mathrm{Fe}$ and from 25 to $50 \mathrm{mg} \cdot \mathrm{kg}^{-1}$ for $\mathrm{Zn}$ (Stone, 1968). (Ponder 2004) documented ranges from 69 to $129 \mathrm{mg} \cdot \mathrm{kg}^{-1}$ for Fe and from 33 to $55 \mathrm{mg} \cdot \mathrm{kg}^{-1}$ for $\mathrm{Zn}$ in leaves of black walnut seedlings. Thus, the results of our study (Table 2) are in general agreement with this published information.

Nutrient retention in root plugs and $N$ uptake efficiency. Increased substrate fertility with nutrient supply (Fig. 3) promoted nutrient uptake by plants at higher availability (Fig. 2, Table 3). However, $\mathrm{N}$ uptake efficiency decreased with increased substrate fertility (Table 3) concurring with results noted elsewhere (Dumroese et al., 2005). The $\mathrm{N}$ unaccounted for by the plants at higher fertility (Table 3 ) was reflected in greater $\mathrm{N}$ retention in the growing media. For example, electrical conductivity (EC), a reflection of soluble salts and substrate fertility, increased at higher fertility (Table 3 ) confirming greater nutrient availability in media (Fig. 3 ). EC is useful for monitoring fertilization protocols (Dumroese et al., 2005; Jacobs and Timmer, 2005; Landis et al., 1989). The EC range found in this study (Fig. 3 ) is within the range of substrate EC recommended $(0.30$ $2.50 \mathrm{ds} \cdot \mathrm{m}^{-1}$ ) for optimum growth of conifer container stock (Phillion and Bunting, 1983; Timmer and Parton, 1984) and below the level $\left(2.60 \mathrm{ds} \mathrm{m}^{-1}\right)$ at which Douglas-fir [Pseudotsuga menziesii (Mirb.) Franco] root penetration was inhibited (Jacobs et al., 2003).

The greater nutrient retention in media at higher fertility (Fig. 3) suggests seedling root plugs acted as sinks for nutrients by storing excess nutrient resources not captured by plants. Such nutrient pools in root plugs could serve as important nutrient sources to fuel new growth of outplanted seedlings (Idris et al., 2004; Timmer and Teng, 2004). Grafted walnut seedlings responded positively to increased nutrient availability, suggesting that fertilization can be used to improve the nutritional quality of grafted black walnut plants in the nursery, which could benefit outplanting performance. Further studies are needed to examine how nursery fertility treatments affect field performance of grafted black walnut stock. Additionally, the hypothesis that root plugs could serve as critical nutrient sources to fuel new growth of outplanted grafted black walnut plants warrants further testing.

\section{Literature Cited}

Beineke, W.F. 1986. Black walnut plantation management. FNR-119. Purdue Univ. Coop. Ext. Serv, West Lafayette, In.

Brown, J.R. (ed.). 1997. Recommended chemical soil test procedures for the North Central Region. NCR publication No 221 (revised). Missouri Agr. Expt. Sta. SB 1001, Columbia, Mo.

Dumroese, R.K. and D.L. Wenny. 1992. Developing a nitrogen balance sheet for container nursery. p. 34-38. In: T.D. Landis, tech. coord. Proc, Intermountain Forest Nursery Association 1991. Gen. Tech. Rpt RM-211. USDA Forest Service, Rocky Mountain Forest and Range Experimental Station. Fort Collins, Colo.

Dumroese, R.K., D.S. Page-Dumroese, K.F. Salifu, and D.F. Jacobs. 2005. Exponential fertilization of Pinus monticola seedlings: Nutrient uptake efficiency, leaching fractions, and early outplanting performance. Can. J. For. Res. 35:2961-2967.

Frak, E., X. Le Roux, P. Millard, S. Guillaumie, and R. Wendler. 2005. Nitrogen availability, local light regime and leaf rank effects on the amount and source of $\mathrm{N}$ allocated within the foliage of young walnut (Juglans nigra $\times$ regia) trees. Tree Physiol. 26:43-49.

Idris, M., K.F. Salifu, and V.R. Timmer. 2004. Root plug effects on early growth and nutrition of black spruce seedlings. For. Ecol. Manage. 195:399-408.

Jacobs, D.F. and V.R. Timmer. 2005. Fertilizerinduced changes in rhizosphere electrical conductivity: relation to forest tree seedling root system growth and development. New For. 30:147-166.

Jacobs, D.F., R. Rose, and D.L. Haase. 2003. Development of Douglas-fir seedling root architecture in response to localized nutrient supply. Can. J. For. Res. 33:118-125.

Jacobs, D.F., F.K. Salifu, and J.R. Seifert. 2005. Growth and nutritional response of hardwood seedlings to controlled-release fertilization at outplanting. For. Ecol. Manage. 214:28-39.

Landis, T.D., D.L. Haase, and R.K. Dumroese. 2005. Plant nutrient testing and analysis in forest and conservation nurseries. In: R.K, Dumroese, L.E. Riley, and T.D. Landis, (tech. coords). National proceedings: Forest and Conservation Nursery Associations-2004. Proc.
RMRS-P-35. USDA Forest Service, Rocky Mountain Forest and Range Experimental Station. Fort Collins, Colo. p. 76-83.

Landis, T.D., R.W. Tinus, S.E. McDonald, and J.P. Barnett. 1989. Seedling nutrition and irrigation. The container tree nursery manual, volume 4 Agric. Handb. 674. USDA Forest Service, Washington, D.C. 119 p.

Phillion, B.J. and W.R. Bunting. 1983. Growth of spruce seedlings at various soluble fertilizer salt levels. Tree Plant. Notes 34:31-33.

Ponder, F., Jr. 1996. Walnut fertilization and recommendations for wood and nut production, pp. 128-137. In: J.W. Van Sambeek (ed.). Knowledge for the Future of Black Walnut Gen. Tech. Rpt. NC-191. USDA Forest Service North Central Forest Experiment Station, St. Paul, Minn.

Ponder, F., Jr 1998. Fertilizer combinations benefit diameter growth of plantation black walnut. J. Plant Nutr. 27:1329-1337.

Ponder, F., Jr. 2004. Soils and nutrient management for black walnut. In: Michler, C.H., P.M. Pijut, J.W. Van Sambeek, M.V. Coggeshall, J. Seifert, K. Woeste, R. Overton, and F. Ponder, Jr. (eds.). Black Walnut in a New Century. Proceedings of the $6^{\text {th }}$ Walnut Council Research Symposium. Gen. Tech. Rpt. NC-243. USDA Forest Service North Central Forest Experiment Station, St. Paul, Minn, p. 71-76.

Salifu, K.F. and V.R. Timmer. 2003. Optimizing nitrogen loading of Picea mariana seedlings during nursery culture. Can. J. For. Res. 33:1287-1294.

Salifu, K.F., M.A. Nicodemus, D.F. Jacobs, and A.S. Davis. 2006. Evaluating chemical indices of growing media for nursery production of Quercus rubra seedlings. HortScience 41: 1342-1346.

SAS Institute, Inc. 2001. SAS/START User's guide version 8.2. SAS Inst, Cary, N.C.

Smith, W., D. Willis, and S.J. Colombo. 2005. Nine different fertilizer regimes still affecting jack pine plantation growth after 12 years. In: S.J. Colombo, (comp.), The Thin Green Line: A Symposium on the State-of-the Art in Reforestation. Proceedings. For. Res. Inf. Pap. No. 160 Ont. Min. Nat. Res. Inst., Sault Ste. Marie, ON p. $164-169$.

Stone, E.L. 1968. Micronutrients of forest tree: a review. In: Forest Fertilization: Theory and practice. Tenn. Valley Authority National Fertilizer Development Center, Muscle Shoals, Ala. p. $132-175$.

Timmer, V.R. and W.J. Parton. 1984. Optimum nutrient levels in container growing medium determined by a saturated aqueous extract. Commun. Soil Sci. Plant Anal. 15:607-618.

Timmer, V.R. and Y. Teng. 2004. Pre-transplant fertilization of containerized Picea mariana seedlings: calibration and bioassay growth response. Can. J. For. Res. 34:2089-2098.

Williams, R.D. 1990. Black walnut (Juglans nigra L.). In: R.M. Burns, Honkala, B.H. tech. coords Silvics of North America: Vol. 2. Hardwoods. Agriculture Handb. 654. USDA Forest Service, Washington, D.C. 877 p. 